\title{
Laparoscopic revision of vertical banded gastroplasty with gastrogastric fistula to sleeve gastrectomy
}

\section{Gastrogastrik fistüllü vertikal bantlı gastroplastinin sleeve gastrektomiye laparoskopik revizyonu}

\section{Hasan Erdem ${ }^{1}$, Mehmet Gençtürk ${ }^{1}$, Serkan Bayıl ${ }^{1}$, Selim Sözen ${ }^{2}$}

\begin{abstract}
Gastrogastric fistula is one of the complications that can occur after vertical banded gastroplasty surgery for weight loss. Sleeve gastrectomy can be performed successfully in patients with gastrogastric fistula in revision surgery. In this study, we present current treatment for the complication of vertical banded gastroplasty (Mason procedure). Revision of vertical banded gastroplasty to sleeve gastrectomy is a safe and feasible option for patients presenting with gastrogastric fistula.
\end{abstract}

Key Words: Vertical gastroplasty, gastrogastric fistula, sleeve gastrectomy.

Öz

Gastrogastrik fistül, kilo kaybı için yapılan vertikal band gastroplasti ameliyatından sonra ortaya çıkabilecek komplikasyonlardan biridir. Revizyon cerrahisinde gastrogastrik fistülü olan hastalarda sleeve gastrektomi başarıyla yapılabilir. Bu çalışmada, vertikal band gastroplasti (Mason prosedürü) komplikasyonu için güncel tedaviyi sunuyoruz. Gastrogastrik fistül ile başvuran vertikal band gastroplastinin, sleeve gastrektomiye revizyonu güvenli ve uygulanabilir bir seçenektir.

Anahtar Kelimeler: Vertikal gastroplasti, gastrogastrik fistül, sleeve gastrektomi.
${ }^{1}$ Istanbul Obesity Surgery (IOC) Clinic, Kurtköy Ersoy Hospital, İstanbul, Turkey. ${ }^{2}$ Sözen Surgery Clinic, İstanbul, Turkey.

HE: $0000-0002-2178-7362$

MG: 0000-0002-6172-0736

SB: 0000-0002-7800-2167

SS: 0000-0003-2006-9198

Informed Consent: The written consent was received from the patient who was presented in this study.

Hasta Onamı: Çalışmada sunulan hastadan yazılı onam alınmıștır.

Conflict of Interest: No conflict of interest was declared by the authors.

Çıkar Çatı̧̧ması: Yazarlar çıkar çatışması bildirmemişlerdir.

Financial Disclosure: The authors declared that this case has received no financial support.

Finansal Destek: Yazarlar bu olgu için finansal destek almadıklarını beyan etmişlerdir.

Geliş Tarihi / Received: 12.01.2020

Kabul Tarihi / Accepted: 10.03.2020

Yayın Tarihi / Published: 20.03.2020

\section{Sorumlu yazar / Corresponding author:}

\section{Selim SÖZEN}

Adres/Address: Sözen Surgery Clinic, İstanbul, Turkey.

e-mail: selimsozen63@yahoo.com

Tel/Phone: 00905055979773

Copyright $\odot$ ACEM 


\section{Introduction}

Vertical banded gastroplasty a primarily restrictive bariatric surgical procedure was first described by Mason [1]. The procedure was performed via laparotomy and a neo-pylorus was constructed with a Dacron or Marlex mesh. The stomach was stapled but not transected. MacLean revised the procedure and performed it laparoscopically with a complete transection of the stomach [2] (Figure 1a, 1b). Gastrogastric fistula (GGF) is one of the important complications that can occur after vertical gastroplasty (VG) surgery for weight loss. In literature, the incidence of the GGF after VG is $2.5 \%$ to $3.5 \%$ [3-5].

Although Roux-en-Y gastric bypass (RYGB) is preferred mostly for revisional surgery, sleeve gastrectomy (SG) can also be performed.

In this study, we present the current treatment for the gastrogastric fistula complication of Mason's procedure.

\section{Case report}

A 39-year-old woman underwent VBG with open surgery for the management of morbid obesity 15 years ago. When nausea and vomiting complaints increased after the operation, she was taken to the operation at the same center again and the laparoscopic mesh ring was removed. When the patient admits to our center, she continued to gain weight again over the years and her BMI was $40 \mathrm{~kg} / \mathrm{m}^{2}$. The physical examination was unremarkable. No comorbidities were present. Routine laboratory investigations did not reveal any specific abnormalities. The patient had a subcostal incision scar belonging to the previous surgery. When examining her during preoperatively, we perform esophagogastroduodenoscopy for the precise anatomy of the former procedure, so we demonstrated the GGF (gastrogastric fistula), just $5 \mathrm{~cm}$ below the gastroesophageal junction (Figure 2) Sleeve gastrectomy was selected and performed for revisional surgery due to weight regain. The postoperative course was uneventful, and the patient was discharged on the postoperative day 7.

The written consent was taken from the patient.

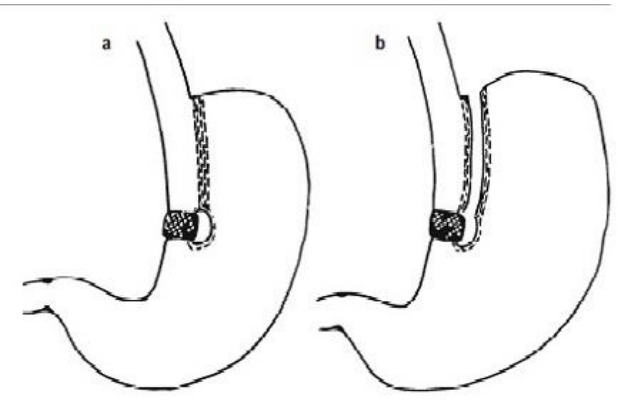

Figure 1: (a) The procedure was performed via laparotomy and a neopylorus was constructed with a Dacron or Marlex mesh. The stomach was stapled but not transected (Mason procedure). (b) Complete transection of the stomach (MacLean procedure).

\section{Surgical Technique}

The operation was started by placing five trocars traditionally. The anatomy was defined by lysing the adhesions between gastric pouch, liver, and the remaining stomach. By intraoperative endoscopy, we identified the GGF. The endoscope was passed to the main stomach, finally entering the duodenum. Here was gastro gastric fistula $5 \mathrm{~cm}$ below the gastroesophageal junction. The gastrocolic ligament was cut through the angle of His with an energy device, and the diaphragmatic crura were exposed. A laparoscopic stapler was introduced and fired consecutively along the length of the endoscope against the greater curve. The gastric pouch was created by using a linear stapler, with two sequential 4.8/60-mm green load firings for the antrum, followed by three sequential $4.8 / 60-\mathrm{mm}$ purple cartridges for the remaining gastric corpus and fundus. At the intraoperative endoscopic control, GGF could not be seen anymore (Figure 3). The resected stomach was extracted through the $15-\mathrm{mm}$ port-site. When the specimen was examined macroscopically, it was observed that the previous vertical stapler line was involved and the vertical stapler area was opened, so she had a gastro gastric fistula. (Figure 4a, 4b). A methylene blue dye test was carried out and did not evidence any leak.

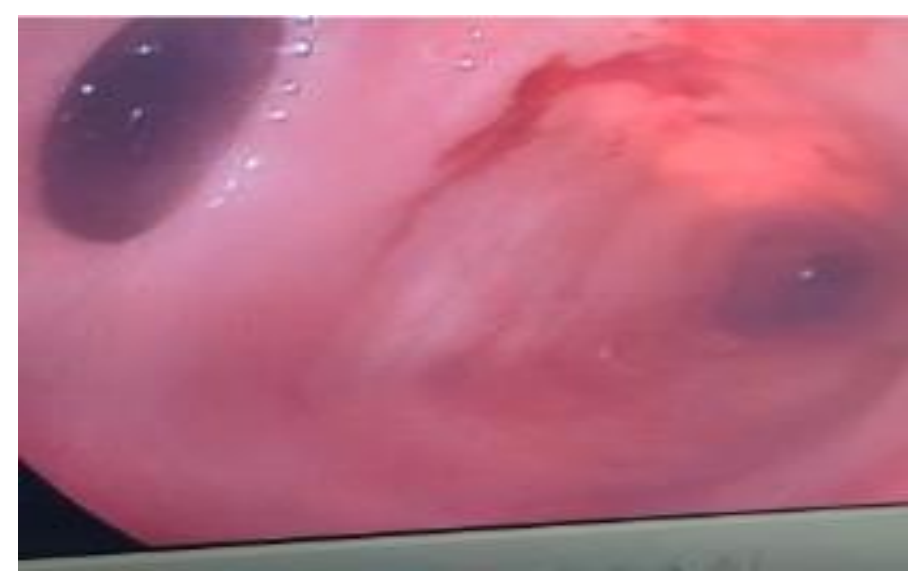

Figure 2: Demonstration of the gastrogastric fistula by esophagogastroduodenoscopy.

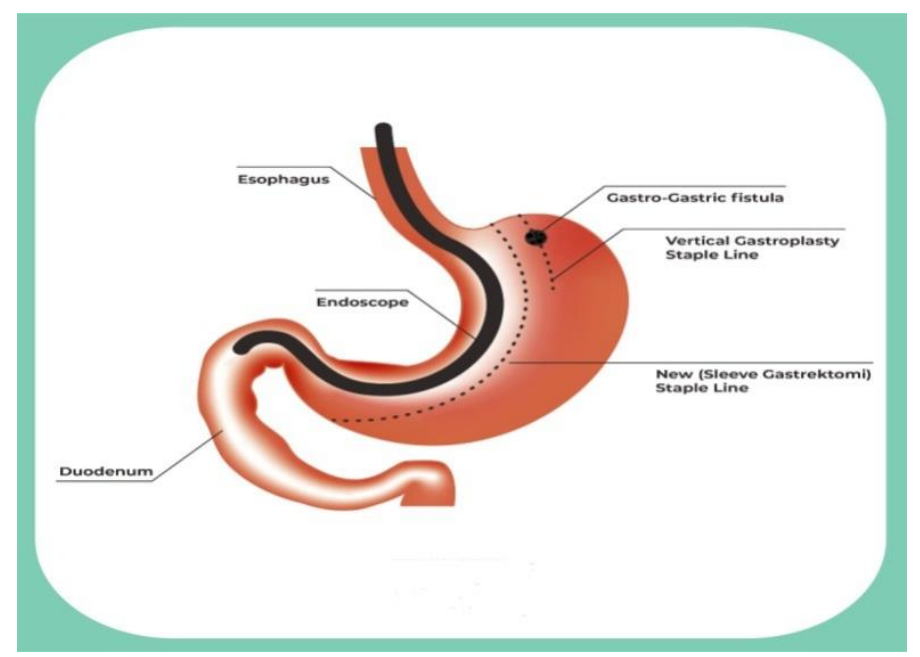

Figure 3: Demonstration for placement of an endoscope before gastric resection.

\section{Discussion}

Vertical band gastroplasty was performed most commonly in 1990th years, although the early results were good, but, there was a return to other surgical procedures in the recent years because of long-term complications and weight regain [6]. Long term complications requiring redo-surgery are common after VBG. Gastric outlet obstruction is a significant complication following VBG, with outlet stenosis rates ranging between $10-20 \%$ of VBG patients [7-9]. As a general consequence of this obstruction, patients develop maladaptive eating strategies leading to significant weight regain [7]. The patient underwent a second surgical operation that mesh under 
pouch was taken off because of the development of gastric outlet syndrome. However, she continued to gain weight over the years.

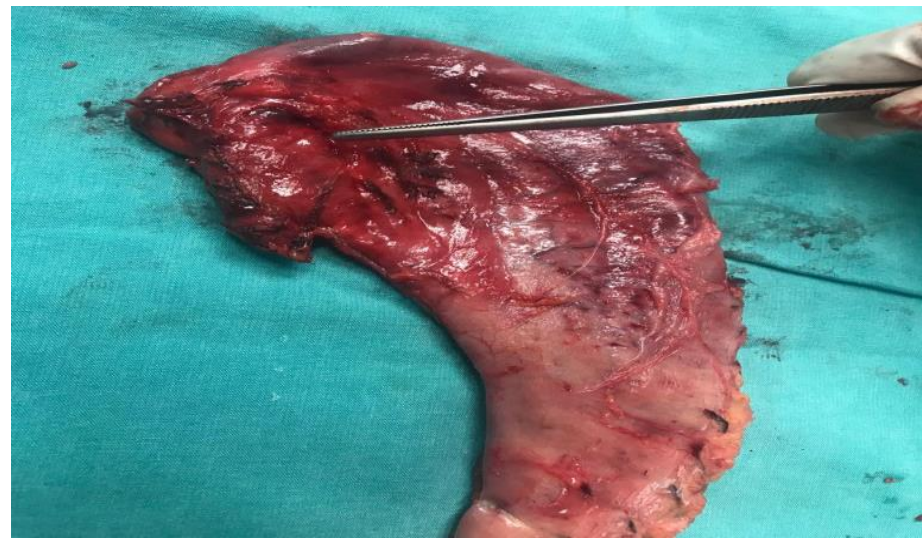

Figure 4: Postoperative anatomy (a) Vertikal gastroplasty stapler line (Please note to new sleeve stapler line, $1.5 \mathrm{~cm}$ away from previous stapler line)

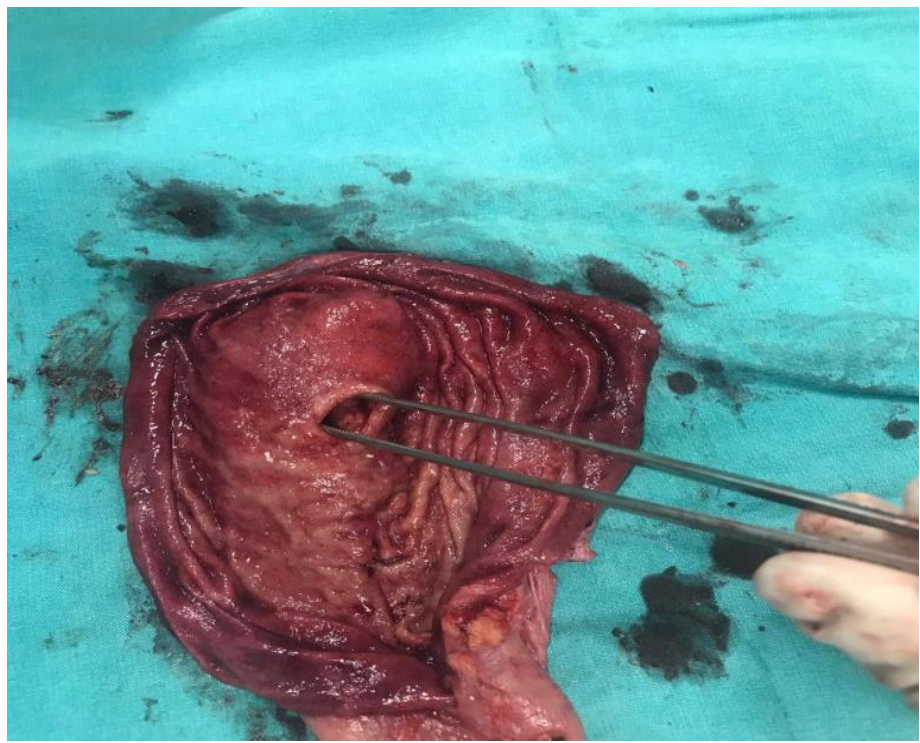

Figure 4 (continued) (b) Opening of the specimen from the greater curvature side and presence of gastrogastric fistula.

Mason procedure was performed via laparotomy and a neo-pylorus was constructed with a Dacron or Marlex mesh. The stomach was stapled but not transected resulting in the long-term $65 \%$ staple line failure rate (gastro-gastric fistula) [10, 11]. MacLean-procedure divided staple lines between the pouch and the remnant stomach. A neo-pylorus was constructed with a small silastic ring. This significantly reduced the risk of the staple line failure and the development of gastro-gastric fistula, which inevitable leads to weight gain [7]. We evaluated that Mason procedure was performed in our patient because of the first surgery operation was 15 years ago and had been gastrogastric fistula.

Sleeve gastrectomy or RYGB could be selected according to the surgeon's experience, and patient's weight status for revisional surgery. Revisional bariatric procedures, in general, are associated with higher complications rate compared to the primary bariatric surgery $[12,13]$. RYGB procedures performed as a secondary revisional procedure after other previous failed procedure [14]. But the group of Cadière et al. [15] recently reported gastro-jejunal leaks in 6 of 43 patients (14 $\%$ ) after conversion of VBG to RYGB. Since our patient had gastrogastric fistula and we were afraid of developing gastrojejunal fistula, our preoperative preparations were in line with sleeve gastrectomy.
Intraoperative endoscopy is important for possible complications and surgical safety when revision surgery is performed in patients with gastrogastric fistula [16].

Although RYGB is preferred mostly, SG can be performed successfully in patients with gastrogastric fistula in revision surgery.

\section{References}

1. Mason EE. Vertical banded gastroplasty for obesity. Arch Surg. 1982;117:701-6.

2. MacLean LD, Rhode BM, Forse RA. A gastroplasty that avoids stapling in continuity. Surgery. 1993;113:380-8.

3. Nocca D, Aggarwal R, Blanc P, Gallix B, Di Mauro GL, Millat B, et al. Laparoscopic vertical banded gastroplasty. A multi center prospective study of 200 procedures. Surg Endosc. 2007;21:870-4.

4. Pasnik K, Krupa J, Stanowski E. Vertical banded gastroplasty: 6 years experience at a center in Poland. Obes Surg. 2005;15:223-7.

5. Mondeturo F, Cappello I, Mazzoni G, Barozzi L, Ghetti A, Nottola D, et al. Radiological contrast studies after vertical banded gastroplasty (VBG) and Roux-en-Y bypass (RYGBP) in patients with morbid obesity. Study of the complications. Radiol Med. 2004;107:51523.

6. Tevis S, Garren MJ, Gould JC. Revisional surgery for failed vertical-banded gastroplasty. Obes Surg. 2011;21:1220-4.

7. Vasas P, Dillemans B, Van Cauwenberge S, De Visschere M, Vercauteren C. Short- and long-term outcomes of vertical banded gastroplasty converted to Roux-en-Y gastric bypass. Obes Surg. 2013;23:241-8

8. Suter M, Jayet C, Jayet A. Vertical banded gastroplasty: longterm results comparing three different techniques. Obes Surg. 2000;10:41-6.

9. van Wezenbeek MR, Smulders JF, de Zoete JP, Luyer MD, van Montfort G, Nienhuijs SW. Long-term results of primary vertical banded gastroplasty. Obes Surg 2015;25:1425-30.

10. Marsk R, Jonas E, Gartzios H, Stockeld D, Granström L, Freedman J. High revision rates after laparoscopic vertical banded gastroplasty. Surg Obes Relat Dis. 2009;5:94-8.

11. Schouten R, Wiryasaputra DC, van Dielen FM, van Gemert WG, Greve JW. Long-term results of bariatric restrictive procedures: a prospective study. Obes Surg. 2010;20:1617-26.

12. Berende CA, de Zoete JP, Smulders JF, Nienhuijs SW Laparoscopic sleeve gastrectomy feasible for bariatric revision surgery. Obes Surg. 2012;22:330-4.

13. Stefanidis D, Malireddy K, Kuwada T, Phillips R, Zoog E, Gersin KS.Revisional bariatric surgery: perioperative morbidity is determined by type of procedure. Surg Endosc. 2013;27:4504-10.

14. Cariani S, Nottola D, Grani S, Vittimberga G, Lucchi A, Amenta E. Complications after gastroplasty and gastric bypass as a primary operation and as a reoperation. Obes Surg. 2001;11:487-90.

15. Cadière GB, Himpens $J$, Bazi $M$, Cadière $B$, Vouche $M$ Capelluto E, et al. Are laparoscopic gastric bypass after gastroplasty and primary laparoscopic gastric bypass similar in terms of results? Obes Surg. 2011;21:692-8.

16. Maselli R, Rizzello M, Genco A, Fantini A, Basso N. Laparoscopic sleeve gastrectomy as revisional surgery in a vertical gastroplasty with gastrogastric fistula: a simplified technique. Surg Laparosc Endosc Percutan Tech. 2011;21:e4-6. 